\title{
PENGARUH KONSENTRASI PELARUT (n-HEKSANA) TERHADAP RENDEMEN HASIL EKSTRAKSI MINYAK BIJI ALPUKAT UNTUK PEMBUATAN KRIM PELEMBAB KULIT
}

\author{
Suratmin Utomo \\ Jurusan Teknik Kimia Fakultas Teknik Universitas Muhammadiyah Jakarta \\ utomosuratmin@yahoo.co.id
}

\begin{abstract}
One effort to utilize waste avocado is by extracting the oil contained in the avocado ore. This study aims at utilization of waste ore avocado while making the material has value ekonmi determine the concentration of the best / optimum solvent $n$-hexane at ekatraksi process for obtaining oil from avocado seed. The research material is being as the avocado seed extractor is $n$-hexane and extraction methods used soklet. The independent variables in this study is the concentration of the extractor and the dependent variable is the yield obtained from ore mimyak avocado. The study was conducted at a temperature of $70^{\circ}$ $C$, the extraction time 4 hours with varying concentrations of $n$-hexane: $60,70,80,90$, and $100 \%$. The results obtained indicate that at $100 \%$ concentration can produce avocado oil extraction of ore at $34.63 \%$ and is the largest yield when compared to other concentration. The relationship between the concentration variables $(x)$ on the acquisition of oil yield expressed by the equation $y=-37.88+0.664 x$ with $R 2=0.962$. Cream made from avocado seed oil produced from the analysis of the market and have met the ISO standard are: obtaining a $\mathrm{pH}$ value 6.52 and a $\mathrm{pH}$ value of 7.6 , while the standard market $\mathrm{SNI} \mathrm{pH}=4.5$ to 8.0; viscosity creamy avocado seed is $25000 \mathrm{cp}$ and cream body lotion on the market standard ISO $5300 \mathrm{cp} 2000-50000 \mathrm{cp}$ and creams for avocado seed moisture content of $77 \%$ and body lotion on the market to $80 \%$, while the standard is $70-90 \%$. Results avocado seed oil cream was applied in the dosage form of type $0 / \mathrm{w}$.
\end{abstract}

Keywords: extraction, cream, avocado seed oil, $n$-hexane, yield

\begin{abstract}
ABSTRAK. Salah satu upaya pemanfaatan limbah buah alpukat adalah dengan mengekstraksi minyak yang terkandung dalam bijih alpukat tersebut. Penelitian ini bertujuan pemanfaatan limbah bijih alpukat sekaligus menjadikan bahan tersebut memiliki nilai ekonmi mengetahui konsentrasi terbaik/optimum pelarut n-hexana pada proses ekatraksi untuk mendapatkan minyak dari biji alpukat. Bahan penelitian adalah biji alpukat sedang sebagai ekstraktor adalah n-heksana dan metode yang digunakan ekstraksi soklet. Variabel bebas dalam penelitian ini adalah konsentrasi ekstraktor dan variabel terikat adalah rendemen mimyak yang diperoleh dari bijih alpukat. Penelitian dilakukan pada temperatur $700 \mathrm{C}$, waktu ekstraksi 4 jam dengan variasi konsentrasi n-heksana: 60, 70, 80, 90, and 100\%. Adapun hasil yang peroleh menunjukkan bahwa pada konsentrasi $100 \%$ dapat menghasilkan rendemen minyak dari bijih alpukat sebesar 34,63\% dan merupakan rendemen terbesar jika dibandingkan dengan konsentrasi lainnya. Hubungan antara variabel konsentrasi $(x)$ terhadap perolehan rendemen minyak dinyatakan dengan persamaan $y=-37,88+0,664 x$ dengan $R 2=0,962$. Krim yang dibuat dari minyak biji alpukat yang dihasilkan dari hasil analisa telah memenuhi pasar dan standar SNI yaitu: memperoleh nilai $\mathrm{pH}$ 6,52 dan nilai $\mathrm{pH}$ di pasaran 7,6 sedangkan standar $\mathrm{SNI} p \mathrm{H}=4,5-8,0$; viskositas krim biji alpukat yaitu $25000 \mathrm{cp}$ dan krim body lotion di pasaran $5300 \mathrm{cp}$ sedangkan standar SNI 2000 - $50000 \mathrm{cp}$ serta untuk kadar air krim biji alpukat sebesar 77\% dan body lotion di pasaran 80\% sedangkan standar yaitu 70-90\%. Hasil minyak biji alpukat diaplikasikan dalam bentuk sediaan krim tipe $\mathrm{o} / \mathrm{w}$.
\end{abstract}

Kata kunci : ekstraksi, krim, minyak biji alpukat, n-heksana, rendemen 


\section{PENDAHULUAN}

Buah alpukat mempunyai kandungan gizi yang tinggi yang berada di dalam daging buahnya, oleh karena itu banyak dikonsumsi sebagai peningkat gizi pada tubuh manusia. Bagian daging dan biji alpukat mengandung minyak yang tinggi, sehingga berpotensi dijadikan seumber minyak Tanaman berbiji umumnya mengandung Lipida pada biji atau buahnya (Eteshola dan Oraedu,1996). Pada umumnya biji alpukat dianggap tidak bermanfaat sehingga dibuang begitu saja menjadi limbah yang belum digunakan secara ekonomis.

Mengingat bahwa buah alpukat pada sebagian besar masyarakat baru dimanfaatkan dagingnya, tetapi kulit maupun biji alpukat belum digunakan sehingga menjadi limbah buangan saja. Padahal, bagian biji alpukat tersebut bila mendapatkan penanganan lebih lanjut dapat menjadi minyak yang tidak kalah nilainya dibanding minyak dari sumber lain. Minyak biji alpukat bisa diproses dan dimanfaatkan menjadi berbagai produk krim yang memiliki nilai ekonomi yang tinggi dan banyak digunakan pada industri kosmetik yang dikenal salah satunya sebagai krim lotion alpukat.

Sediaan krim dari mijyak alpukat sudah banyak di pasaran dengan bebagai jenis dan merk dagang. Penggunaan alpukat bisa disesuaikan untuk kebutuhan dan fungsi dari kandungan alpukat. Untuk tujuan ini dibutuhkan suatu inovasi untuk menciptakan suatu sediaan dari alpukat yang memaksimalkan fungsi dari kandungan biji alpukat. Buah alpukat saat ini tersedia banyak di masyarakat dan bagian biji belum digunakan dengan baik, oleh karena itu perlu dilakukan pegkajian kemanfaatan bijinya.. Minyak biji alpukat dapat diperoleh dengan menggunakan metode ekstraksi dengan menggunakan ekstraktor (solven) organik.

Secara umum penelitian ini bertujuan untuk memaksimalkan manfaat atau meningkatkan nilai tambah dari biji buah alpukat, mengembangkan inovasi dari manfaat buah alpukat menjadi suatu sediaan kosmetik yaitu krim tipe o/w. Sedangkan dari kajian keilmuan penelitian ini dilakukan untuk mencari hubungan antara konsentrasi solven dengan perolehan rendemen minyak biji alpukat dengan cara ekstraksi dengan luaran minyak biji alpukat dan krim hasil pengolahan dari minyak biji alpukat.

Dengan demikian penelitian ini memiliki manfaat antara lain: membantu pengurangan limbah, meningkatkan ekonomi masyarakat yang berkaitan langsung dengan limbah biji alpukat serta memberikan informasi kepada pemangku kebijakan khususnya daerah yang berpotensi keberadaan limbah biji alpukat dalam pemanfaatannya.

Alpukat atau avokad dari istilah Aztek yaitu ahuacatl. Suku Aztek ada di Amerika Tengah, Meksiko dan Guam, inilah daerah asal buah ini. Ketika pasukan Spanyol masuk ke wilayah itu pada abad ke-16, alpukat dan buah lain, diperkenalkan (Lu, dkk., 2005).

Amerika Selatan dan Amerika Tengah merupakan daerah budidaya alpukat dan diperkenalkan oleh Martín Fernández de Enciso, sejak 1519. Abad 18 masuk Indonesia dan pada tahun 1920 sampai dengan 1930, telah masuk 20 varietas alpukat dari Amerika Tengah dan Amerika Serikat untuk mendapatkan varietas yang baik, untuk peningkatan kesehatan dan gizi masyarakat. Maka alpukat mulai dikenal oleh penduduk dunia. Tanaman alpukat (Persea americana Mill) berupa pohon dengan nama alpuket (Jawa Barat), alpokat (Jawa Timur/Jawa Tengah), boah pokat, jamboo pokat (Batak), advokat, jamboo mentega, jamboo pooan, pookat (Lampung) dan lain-lain.

Menurut Gomez-Lopez (2000), alpukat secara umum dibagi menjadi jenis West Indian, Guatemalan, Mexican. Daging kehijauan di bawah lapisan kulit dan menguning pada biji. Kulit berwarna hijau disebabkan adanya klorofil atau hitam disebabkan pigmen antosianin. Pohon alpukat berupa batang berkayu, bulat, bercabang, coklat, kotor dengan tinggi 3$10 \mathrm{~m}$, memiliki daun bertangkai, berjejaljejal pada ujung ranting, berbentuk bulat 
telur memanjang, dan waktu muda berambut rapat. Bunga berkelamin dua, dalam malai yang bertangkai dan berbunga banyak, terdapat dekat ujung ranting.

Alpukat memiiki biji dengan bentuk bola berdiameter 2,5 sampai dengan $5 \mathrm{~cm}$ merupakan bagian yang berkembang dari ovule (bakal biji) dan mempunyai peran sebagai komponen regenerasi pada tanaman. Biji merupakan salah satu sumber pangan untuk manusia dan hewan. Manfaat lain adalah sebagai obatobatan, fiber (kapas), minuman (kopi dan coklat), dan sumber minyak (Esau,1977). Biji alpukat mengandung senyawa polifenol, flavonoid, triterpenoid, kuinon, tanin. asam tannic, gallotannin, atau corritaginang mempunyai kemampuan sebagai adstringen (Imroatossalihah, 2002).

Kandungan lemak pada biji alpukat sebesar 1 - 1,5\%, dengan komposisi: asam palmitat sebesar $12,87 \%$; asam strearat sebesar 1,45\%; asam oleat sebesar $57,44 \%$; asam palmitoleat sebesar 3,86\%; asam linoleat sebesar 6,3$11,3 \%$ dan asam miristat sebesar $0,06 \%$. Asam Miristat digunakan pada kosmetik yang mampu menyerap minyak di kulit. Asam palmitat umum terkandung dalam minyak kelapa sawit dan minyak alpukat serta makanan yang berlemak tinggi. Asam strearat digunakan sebagai bahan baku kosmetik, lilin, plastik, untuk memperkeras sabun, dll. Asam oleat digunakan dalam industri farmasi yaitu sebagai pelarut dan pengental untuk obatobatan tertentu dan bahan aerosol. Asam palmitoleat belum digunakan secara umum, namun diketahui bahwa asam palmitoleat dapat digunakan sebagai suplemen diet. Asam linoleat digunakan sebagai bahan pembuat sabun dan pengental, sedangkan dalam industri makanan biji alpukat dipakai sebagai pewarna (Kakuda dan Kamel, 1992).

Solven pada umumnya adalah zat berupa senyawa karbon cair baik jenis alifatik maupun aromantik. Senyawa karbon yang bisa digunakan sebagai solven antara lain heksana dan etanol.
Heksana, adalah suatu hidrokarbon alkana dengan rumus kimia $\mathrm{C} 6 \mathrm{H} 14$. Heksana merupakan hasil refining minyak mentah. Komposisi dan fraksinya dipengaruhi oleh sumber minyak. Umumnya berkisar $50 \%$ dari berat rantai isomer dan mendidih pada $60-70^{\circ} \mathrm{C}$. Seluruh isomer heksana dan sering digunakan sebagai pelarut organik yang bersifat inert karena non-polarnya. Banyak dipakai untuk ekstraksi minyak dari biji, misal kacang-kacangan dan flax. Rentang kondisi distilasi yang sempit, maka tidak perlu panas dan energy tinggi untuk proses ekstraksi minyak. Dalam industri, heksana digunakan dalam formulasi lem untuk sepatu, produk kulit, dan pengatapan serta untuk pembersihan. $\mathrm{n}$ heksana juga dipakai sebagai agen pembersih produk tekstil, meubeler, sepatu dan percetakan (Atkins, 1987).

Etanol, adalah pelarut volatile bagi senyawa organik, bersifat semipolar karena dapat melarutkan baik senyawa polar maupun nonpolar sehingga dapat saling larut dengan air. Kepolaran ini diakibatkan adanya gugus polar $-\mathrm{OH}$ dan nonpolar yaitu etil ( $\mathrm{CH} 3 \mathrm{CH} 2-)$. Rantai karbon pendek mengakibatkan sifat semipolar. Solven semipolar bisa menginduksi tingkat polaritas pelarut nonpolar, menjadi pelarut antara untuk mencampur pelarut polar dan nonpolar (Atkins, 1987). Menurut Smith, 1994 etanol merupakan pelarut yang bersifat sangat selektif terhadap reaksi. Dasar pertimbangan penggunaannya adalah selektif, kelarutannya, densitasnya, reaktif, dan titik didih. Mampu melarutkan ekstrak dalam jumlah besar, beda densitas signifikan sehingga mudah dalam memisahkan zat terlarut. Etanol bersifat non toksik, tidak eksplosif jika berada di udara, tidak korosif dan mudah diperoleh. Wujud etanol cair, bersifat volatil, kelarutan tergantung tergantung panjangnya rantai $\mathrm{C}$, semakin panjang semakin sukar larut, dan semakin panjang gugus alkil $(R)$ maka semakin polar. Dari sifat-sifat tersebut maka etanol juga bisa digunakan sebagai bahan ekstraktor minyak dari biji-bijian. 
Minyak adalah salah satu golongan lipid, yaitu senyawa organik yang ada di alam dan tidak larut di dalam air, tapi larut dalam pelarut organik nonpolar, seperti dietil eter, kloroform, benzena dan hidrokarbon lainnya yang polaritasnya sama. Minyak adalah trigliserida atau triasgliserol, merupakan triester senyawa gliserol. Hidrolisis terhadap minyak menghasilkan asam karboksilat dan gliserol.

Biji alpukat mengandung minyak nabati, menurut Rachimoellah (2009), biji alpukat dapat dijadikan sebagai salah satu dari 9 sumber minyak nabati. Minyak biji alpukat merupakan produk baru yang sekarang mulai banyak digunakan. Beberapa negar penghasil adalah Meksiko (34\%), USA $(8 \%)$, Israel (4\%), Afrika Selatan (<2\%), dan Selandia Baru $(<1 \%)$, dan negaranegara juga membudidayakan dan memperdagangkan buahnya (Eyres dkk., 2006). Minyak biji alpukat enak rasanya dan banyak manfaatnya bagi kesehatan (Litz dkk., 2007). Banyak keuntungan dari Minyak biji alpukat, dari data dapat diketahui bahwa mengkonsumsi minyak biji alpukat dapat mengurangi serum total kolesterol, LDL (Low Densisty Lipoprotein), trigliserida, dan meningkatkan kadar HDL (High Densisty Lipoprotein). Minyak biji alpukat menurunkan kemungkinan terserang aterosklerosis, penyakit kardiovasular (Ortiz-Moreno dkk., 2003; Alvizouri-Munoz dkk.,1992).

Tidak hanya dalam bidang kesehatan, minyak biji alpukat dimanfaatkan pula pada produk kecantikan sebagai aditif antibakteri dan mengurangi kerutan. Kandungan minyak biji alpukat yaitu vitamin E, lemak esensial, antioksidan, asam oleat mencegah terserapnya kolesterol dan trigliserid ke darah, serta omega 3 minyak ini diketahui mampu mencegah kanker. Kandungan asam lemak omega-3 dan omega-6 menghambat tumbuhnya tumor. Asam lemak tidak jenuh dan vitamin $\mathrm{E}$ baik untuk jantung, sehingga minyak alpukat bisa digunakan sebagai minyak goreng. Selain itu minyak alpukat bisa mengurangi LDL potasium yang dapat menaikkan tensi.
Minyak biji alpukat bagus untuk kulit dan rambut, oleh karenanya banyak digunakan untuk bahan kosmetik. Manfaat lain adalah sebagai pelembab, penetrasi kulit, dalam sediaan kosmetik. Sifat penetrasi tinggi dapat mempengaruhi kecepatan terapi. Minyak biji alpukat bisa diperoleh dengan cara ekstraksi dan hasilnya minyak alpukat lebih efektif dibandingkan dengan minyak zaitun. (Widioko, 2009). Kandungan asam lemak minyak biji alpukat adalah:

Asam lemak miristat sebanyak 0,06\%

Asam lemak Palmitat sebanyak $12,87 \%$

Asam lemak Palmitoleat sebanyak 3,86\%

Asam lemak stearat sebanyak 1,45\%

Asam lemak Oleat senbanyak 57,44\%

Asam lemak Linoleat sebanyak 18,7 \% (Hidayat, 2009)

Tabel 1 Sifat fisik dan kimia minyak biji alpukat.

\begin{tabular}{|c|c|}
\hline Sifat Fisik & Sifat Kimia \\
\hline Berat & FFA \\
\hline 0,915 & $0,367-0,82 \%$ \\
\hline 0,916 & Bilangan Saponifikasi \\
\hline Titik didih & $(\mathrm{mg} \mathrm{KOH} / \mathrm{g}): 246,840$ \\
\hline$: 10,500 C$ & Bilangan lodin (mg \\
\hline Flash point & $: 42,664$ \\
\hline$: 2450 \mathrm{C}$ & Asam (mg \\
\hline Indeks Bias & $\mathrm{KOH} / \mathrm{g})$ \\
\hline$: 1,462$ & Bilangan Ester \\
\hline Viskositas & $: 241,640$ \\
\hline 0,357 poise & $\begin{array}{l}\text { Bilangan Peroksida } \\
(\mathrm{meq} / 1000 \mathrm{~g}): 3,3\end{array}$ \\
\hline & Bahan yan tak \\
\hline & $\begin{array}{l}\text { tersabunkan : } 15,250 \\
\%\end{array}$ \\
\hline
\end{tabular}

(Kurniawan, 2014)

\section{Basis Krim}

Basis merupakan komponen terbesar dalam suatu sediaan semipadat (seperti pasta, salep, krim, dII).Salah satu faktor yang harus diperhatikan dalam formulasi sediaan semi padat adalah pemilihan/seleksi basis yang cocok/sesuai. Dalam obat, basis merupakan parameter penentu kereaktifan obat, sehingga berpengaruh terhadap kemanjuran pengobatan, akibatnya formulasi obat harus tepat. Basis tidak selamanya sesuai bagi semua zat aktif, tipe kulit, dan tempat aplikasi juga terhadap berbagai penyakit, Oleh karena 
itu perlu dikaji lebih jauh tentang sifat-sifat kimia-fisika obat dan sasaran terapi (Farmakope Indonesia).

Ada 5 macam basis dalam sediaan semi padat yaitu: (1) Basis Hidrokarbon (Oleaginous); (2) Basis Absorbsi (anhydrous); (3) Basis Absorbsi (W/O type); (4) Basis terlarut; (5) Basis Tercuci (O/W type). Basis tercuci tipe oil in water atau OM merupakan salah satu basis yang digunakan dalam sediaan semi padat. Basis salep ini adalah emulsi minyak dalam air $(\mathrm{O} / \mathrm{W})$ antara lain setiap hidrofilik (krim). Basis salep bisa dibersihkan menggunakan air, menggunakan lap basah, sehinggabisa digunakan sebagai alas kosmetik. Aditif pengawet krim yang banyak dipakai adalah metil paraben (nipagin) dengan kandungan $0,12 \%$ - $0,18 \%$ atau propil paraben (nipasol) dengan kandungan $0,02 \%-0,05 \%$.

Prinsip pembuatan krim melalui 3 tahap, (1) Tahap pencampuran yaitu dimulai dari penghancuran aglomerat menjadi partikel dengan ukuran homogen kemudian dilanjutkan dengan pelarutan untuk mendapatkan sediaan yang homogeny, (2) Tahap pemanasan yaitu membuat sediaan setengah padat dipanaskan terlebih dahulu, agar saat homogenisasi bahan tidak memerlukan penanganan yang rumit, kecuali jika ada bahan-bahan tersebut yang bersifat termolabil, (3) Tahap pendinginan yaitu selalah didapatkan capuran atau larutan yang homogen bahan tersebut didinginkan pada suhu ruang. Sifat basis krim tipe O/W antara lain: kental, berwarna putih, tidak berbau, berkadar air 80 - $90 \%$, viskositas $20.000-40.000 \mathrm{cP}$ dan $\mathrm{pH}=$ $6-7$.

\section{Sediaan Krim dengan ekstrak minyak biji Alpukat}

Krim adalah bahan semi padat berbentuk emulsi dengan tipe air di dalam minyak atau sebaliknya dan biasanya dipakai sebagai pelembab atau obat kulit, (Ansel, 1989). Sediaan semi padat berisi satu atau lebih bahan di dalam bahan dasarnya. Sediaan setengah padat merupakan sediaan yang konsistensi fase cair dibuat formulasinya dalm bentuk emulsi. Formulasi ini tersusun dari minyak dalam air atau tersebarnya Kristal asam lemak atau alkohol rantai panjang di dalam air, bisa dibersihkan dengan air dan dipakaidalam formula kosmetika. Tujuan umum dibentuknya sediaan krim adalah untuk mendapatkan efek emolien atau pelembut.

Berdasarkan fase terdispersinya, krim digolongkan menjadi 2 tipe, yakni tipe air terdispersi dalam minyak $(\mathrm{a} / \mathrm{m})$ dan krim minyak yang terdispersi dalam air (m/a). Kestabilan krim akan terganggu / rusak jika sistem campurannya mengalami gangguan, karena perubahan temperatur dan komposisi, karena adanya fase yang berubah secara berlebihan atau emulsifier tidak tercampur dengan baik. Pemakaian krim memiliki kelihan yaitu: mudah dan merata; praktis; mudah dibersihkan atau dicuci; cara kerja berlangsung secara setempat; tidak lengket terutama tipe m/a; memberikan rasa dingin (cold cream) tipe $\mathrm{a} / \mathrm{m}$; digunakan sebagai kosmetik.

Parameter untuk menentukan mutu krim adalah: (1) Kestabilan krim pada suhu dan kelembaban yang ada dalam kamar ; (2) Lunak, yaitu bahan halus dan homogeny; (3) Penggunannya mudah, umumnya krim tipe emulsi adalah yang paling mudah dipakai dan dihilangkan dari kulit; (4) Obat terdispersi merata melalui dasar krim baik fase padat maupun cair pada penggunaan (Anief, 1994).

\section{Proses Pembuatan Minyak Biji Alpukat}

Pembuatan minyak dari biji melalui tahapan ekstraksi dilanjutkan dengan evaporasi.

Ekstraksi adalah proses penarikan suatu zat dari sumber bahan (campuran) dengan pelarut cair (ekstraktor) sehingga zat terpisah dari komponen lain yang tidak dapat larut dalam pelarut. Campuran antara fluida padat dan cair sulit untuk dipisahkan, baik secara mekanik maupun termal. Hal ini disebabkan karena zat penyusunnya saling larut, sensitive terhadap panas erat, peka terhadap panas, perbedaan karakter fisiknya sangat kecil, dan konsentrasinya sangat kecil. 
Keadaan seperti itu bisa diatasi dengan menggunakan metode pemisahan ekstraksi, karena cara ini paling murah. Ekstraksi merupakan metode pemisahan yang cepat dan bersih, baik untk senyawa organic,anorganik, baik untuk uji mikro maupun makro. Penggunaan ekstraksi antara lain untuk uji kimia, sintesa skala laboratorium untuk bahan kimia organik, biokmia, dan anorganik. Tujuan ekstraksi untuk memisahkan satu bahan dari campuran bahan dengan bantuan solven (Othmer, 1999).

Salah satu bentuk ekstraksi adalah dengan metode sokletasi digunakan untuk ekstraksi suatu senyawa dari material atau bahan padat dengan pelarut panas. Alat yang digunakan adalah labu didih, ekstraktor dan kondensor. Sampel sebelum disokletasi dikeringkan dan dihaluskan untuk mengilangkan kandungan air yang terdapat dalam sampel sedangkan dihaluskan adalah untuk mempermudah senyawa terlarut dalam pelarut. Jumlah pelarut akan berpengaruh jumlah perolehan ekstrak hal ini sebabkan karena adanya kontak antara solven dengan zat sampel makin besar. Ekstraksi ini disertai dengan pemanasan dan hasil ekstraksi adalah larutan minyak dengan ekstraktor kemudian dipisahkan memlalui penguapan, hasilnya adalah minyak (produk) yang dinginkan dan solven yang semula kembali (Shreve, 1967).

Untuk pembuatan krim minyak biji alpukat, yaitu dengan melarutkan minyak biji alpukat konsentrasi $1 \%$ sebanyak $2,5 \mathrm{~g}$ ke dalam basis krim sebanyak $250 \mathrm{ml}$.

Dari uraian teori tersebut di atas perihal hubungan antara konsentrasi pelarut $n$ heksana dengan rendemen hasil ekstraksi maka dapat diduga bahwa semakin tinggi konsentrasi n-heksana, maka semakin besar hasil rendemen minyak yang diperoleh.

\section{METODOLOGI PENELITIAN}

\section{Bahan dan Alat}

Bahan yang digunakan antara lain buah alpukat, n-heksana, basis krim.

Alat yang digunakan antara lain timbangan, rangkaian alat sokletasi, batang pengaduk, beaker glass, erlemeyer, gelas ukur, blender, ph meter, vikometer, moisture balance.

\section{Metode Penelitian:}

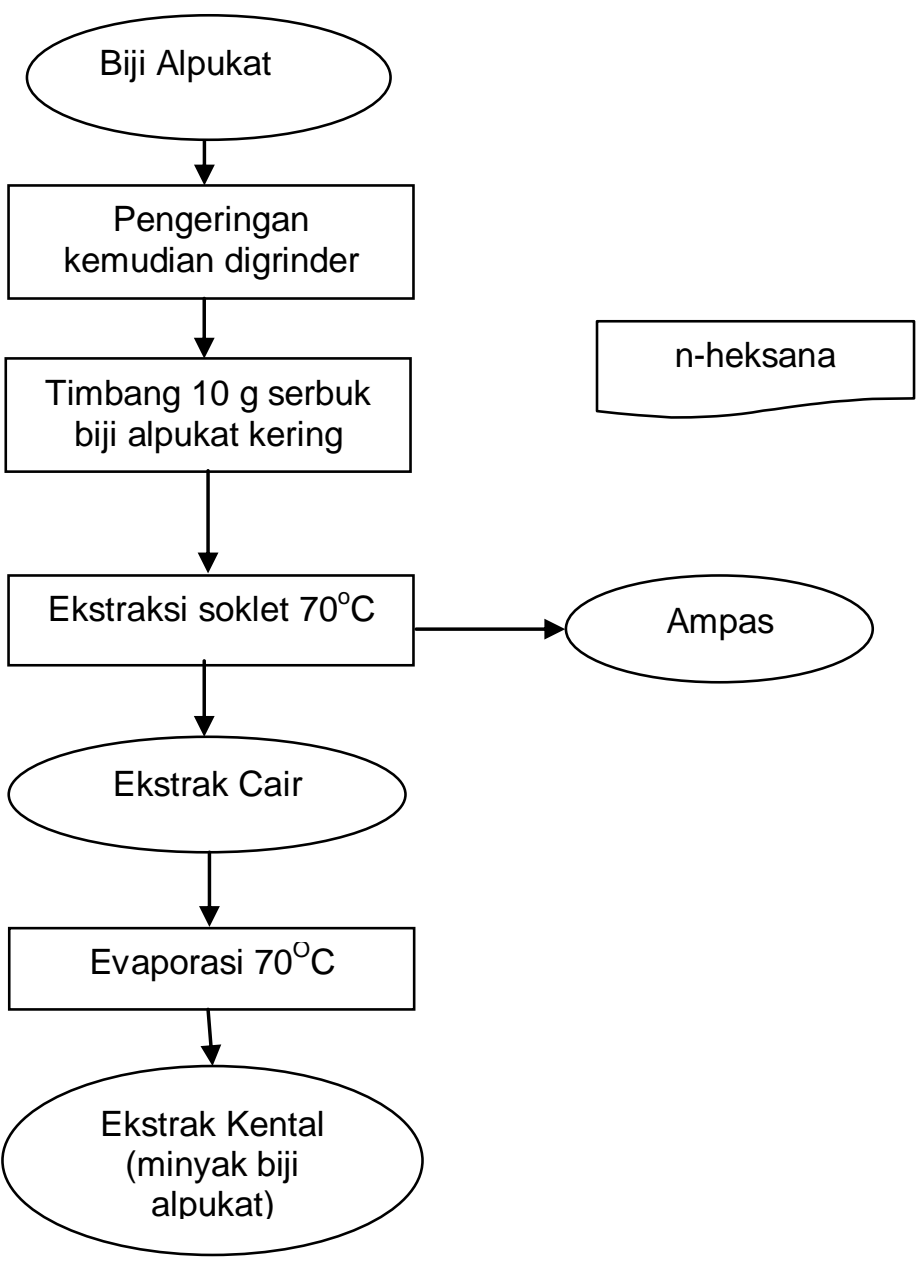

Gambar 1. Diagram proses ekstraksi minyak biji alpukat 


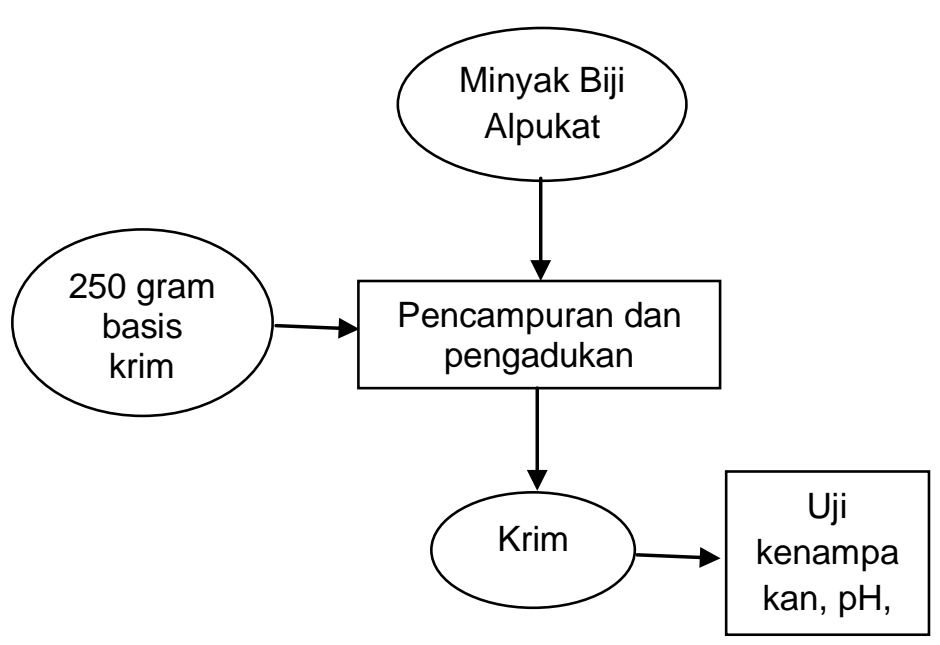

Gambar 2. Diagram proses pembuatan Krim

\section{HASIL DAN PEMBAHASAN}

\section{Data Hasil Penelitian}

Tabel 2: Pengaruh konsentrasi pelarut (heksana) terhadap rendemen minyak, pada temperatur $70^{\circ} \mathrm{C}$.

\begin{tabular}{|c|c|c|c|}
\hline $\begin{array}{l}\text { Konsentrasi } \\
\text { pelarut (\%) }\end{array}$ & $\begin{array}{l}\text { Berat } \\
\text { biji } \\
\text { alpukat } \\
\text { (g) }\end{array}$ & $\begin{array}{l}\text { Berat } \\
\text { hasil } \\
\text { (g) }\end{array}$ & $\begin{array}{l}\text { Rendemen } \\
\text { minyak } \\
(\%) \rightarrow\end{array}$ \\
\hline 60 & 10,56 & 0,89 & 8,43 \\
\hline 70 & 10,35 & 1,17 & 11,30 \\
\hline 80 & 10,13 & 1,73 & 17,08 \\
\hline 90 & 10,03 & 2,54 & 25,32 \\
\hline 100 & 10,31 & 3,57 & 34,63 \\
\hline
\end{tabular}

Tabel 3: Perbandingan spesifikasi krim hasil penelitian dengan krim produk di pasar.

\begin{tabular}{lllll}
\hline Sampel & Parameter & & & \\
\cline { 2 - 5 } & Kenampakan & $\mathrm{pH}$ & Viskositas & $\begin{array}{l}\text { Kadar } \\
\text { air }\end{array}$ \\
\hline $\begin{array}{l}\text { Krim } \\
\text { minyak }\end{array}$ & Homogen & 6,5 & $\begin{array}{l}25.000 \\
77 \%\end{array}$ \\
$\begin{array}{l}\text { biji } \\
\text { alpukat }\end{array}$ & 2 & $\mathrm{cP}$ & \\
\hline $\begin{array}{l}\text { Krim } \\
\text { produk } \\
\text { pasar }\end{array}$ & Homogen & 7,6 & $5300 \mathrm{cP}$ & $80 \%$ \\
\hline
\end{tabular}

\section{Pembahasan}

\section{Rendemen Minyak Alpukat}

Dari data pada tabel 2 dapat plot sebagaimana gambar grafik berikut.

Hubungan antara konsentrasi pelarut $(x)$ dengan rendemen minyak hasil ekstraksi

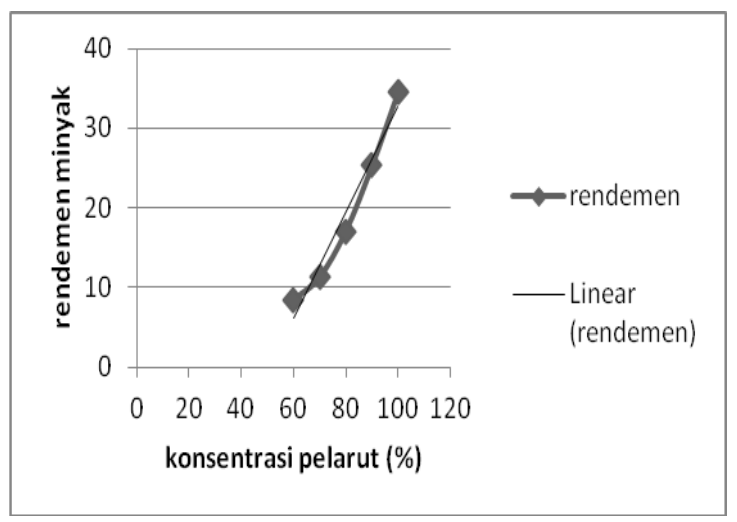

Gambar 3. Hubungan antara konsentrasi pelarut terhadap rendemen minyak

(y) dinyatakan dengan persamaan $\mathrm{y}=$ $37,88+0,664 \times$ dengan $R 2=0,962$. Dari persamaan diatas dapat dijelaskan bahwa, rendemen akan bernilai positif jika ektraksi menggunakan solven dengan konsentrasi $\geq 57,05 \%$ atau dengan kata lain jika komposisi solven (n-heksana) dalam proses ekstraksi kurang dari 57,05\% maka ekstraksi tidak mengahasilkan minyak. Ekstraksi dengan menggunakan komposisi solven $100 \%$ pada temperatur 70oC dalam waktu 4 jam mengasilkan rendemen yang terbaik (tinggi) dan persamaan tersebut menunjukkan bahwa makin tinggi komposisi solven, maka makin tinggi minyak yang diperoleh dari biji alpukat.

\section{Uji Spesifikasi Krim}

Hasil analisis krim yang ditunjukkan pada tabel 3, nampak bahwa dengan membandingkan parameter antara krim hasil penelitian dan krim beredar di pasar menunjukkan yakni: sama - sama homogen; $\mathrm{pH}=6,52$ dan 7,6; kadar air 77 $\%$ dan $80 \%$ sedangkan viskositas adalah $25.000 \mathrm{cP}$ dan $5300 \mathrm{cP}$. Walaupun ada perbedaan nilai parameter antara krim hasil penelitian dengan krim yang beredar di pasar, namun nilai-nilai parameter krim dari hasil penelitian masuk dalam spesifikasi SNI yaitu krim pelembab kulit yaitu $\mathrm{pH}$ di SNI 4,5 - 8,0; kadar air $70-$ $90 \%$ dan viscositas $2000-50000 \mathrm{cP}$. 


\section{KESIMPULAN}

\section{Kesimpulan}

Biji alpukat dapat menghasilkan minyak melalui ekstraksi sehingga merupakan salah satu sumber minyak nabati.

Ekstraksi minyak dari biji alpukat dapat dilakukan dengan solven n-heksana dalam kondisi temperatur $70 \circ \mathrm{C}$ dan waktu 4 jam dapat menghasilkan rendemen 34,6\% dengan komosisi solven sama dengan sampel biji alpukat.

Hubungan antara komposisi solven dengan perolehan rendemen dinyatakan dengan persamaan $Y=0,664 x-37,88$, dengan $R=0,962$, ini menunjukkan bahwa semakin besar komposisi solven maka rendemen minyak yang diperoleh melalui ekstraksi makin banyak dan komposisi solven minimal untuk mendapatkan minyak adalah $57,05 \%$.

\section{DAFTAR PUSTAKA}

Alvizouri-Munoz M, Carranza-Madrigal J, Herrera-Abarca JE, Chavez-Carbajal F, Amezcua-Gastelum JL. . 1992. Effects of avocado as a source of monounsaturated fatty acids on plasma lipid levels. Arch Med Res ;1:163-7

Anief, M., 1994. Farmasetika. Gadjah Mada University Press. Yogyakarta. 113-132.

Ansel,H.C., (1989). Pengantar Bentuk sediaan Farmasi. Edisi 4. UI Press. Jakarta. Halaman 96,147.

Atkins P.W.,1987. Physical chemistry, 2nd Oxford ELBS

Esau, K. 1977. Anatomy of seed plants 2nd edition. John Wiley \& Sons, Inc. Canada

Eyres, L.; Sherpa, N; Hendriks, G. 2006. Avocado Oil- $A$ new edible Oil from Australasia. Institute of Food, Nutrition and Human Health, Massey University, New Zealand
Eteshola, E., A., Oraedu, C. I.. 1996. Fatty acid compositions of tigernut tubers (Cyperus esculentus), baobab sedes (Adansonia digitata), and their mixture. JAOCS 73 (2): 255-257.

Gomez-Lopez, V.C. 2000. Fruit Characterization of Venezuelan Avocado Varieties of medium oil content. Scientia Agricola V. 57 N.4 p. 791-794.

Hidayat, Wahyu. 2008, Manfaat Alpukat (online) (http://www.google.com) diakses 20 Maret 2015. Farmakope Indonesia.

Imroatossalihah. 2002. Daging Buah, Daun dan Biji Alpukat sebagai Bahan Obat Ditinjau dari Segi Kedokteran. Skripsi. Program Sarjana Fakultas Kedokteran YARSI, Jakarta

Kakuda Y., B. S. Kamel. 1992. Fatty acids in fruits and fruits products. Marcel Dekker Inc. New York.

Litz RE, Raharjo SHT, Gómez-Lim MA (2007) Avocado. In: Pua EC, Davey $M R$ (eds) Transgenic crops $V$. Biotechnology in agriculture and forestry. Springer, Berlin, pp 167187

Lu Q.-Y., Arteaga J. R., Zhang Q., Huerta S., Go V. L., Heber D. 2005. Inhibition of prostate cancer cell growth by an avocado extract: Role of lipid-soluble bioactive substances. J. Nutr. Biochem. ;16:23-30.

NN. 2008. Hexane. (Online). (http://wikipedia.org, diakses 15 Maret 2015)

Ortiz-Moreno, A., Dorantes, L., Gal'ındez, J. and Guzman, R. 2003. Effect of different extration methods on fatty acids, volatile compounds, and physical and chemical properties of avocado (Persea Americana Mill) oil. Journal Agricultural Food Chemistry 51, 2216-2221. 
Kirk-Othmer, 1999. Concise Encyclopedia of Chemical Technology. Fourth Edition, A John Wiley \& Sons, Inc., Publication.

Kurniawan, Reiza Frandika. 2014. Khasiat Dahsyat Alpukat : Mengobati dan Mencegah Semua Penyakit. Jakarta: Mahadaya Langit.

Rachimoellah, H.M., Resti, Dyah Ayu., Zibbeni, et. al., Production of Biodiesel through Transesterification of Avocado (Persea Gratissima) Seed Oil Using Base Catalyst, Jurnal Teknik Mesin, Vol. 11, No. 2, 2009.

Shreve, Norris R., 1967., The Chemical Process Industries, Kogakusha Company, Ltd.

Smith, Michael B., 1994. Organic Synthesis. McGraw-Hill-Inc. New York

Widioko, Septian Ardi dan Wawan Rustyawa.2009. Ekstraksi Kontinyu Lawan Arah dengan Simulasi Batch Tiga Tahap Pengambilan Minyak Biji Alpukat Menggunakan Pelarut $N$ Heksana dan Iso Propil Alkohol. Universitas Diponegoro, Semarang 